\title{
BRITISH COLONIALISM AND THE INDIRECT RULE: A HIERARCHICAL ADMINISTRATIVE STRUCTURE TO CONTROL THE UNRULY TRIBES \\ Raid Khan $^{1}$, Asif Salim², Zarmina Baluch ${ }^{3}$, Komal Mehreen ${ }^{4}$, Muhammad Kaleem ${ }^{5^{*}}$
}

${ }^{1} \mathrm{PhD}$ in International Relations, Department of International Relations, University of Peshawar, Pakistan; ${ }^{2}$ Assistant Professor, Department of Political Science, Bacha Khan University, Charsadda, Pakistan; ${ }^{3}$ Lecturer, Department of Political Science Islamia College University Peshawar, Pakistan; ${ }^{4} \mathrm{PhD}$ Scholar, Department of Communication \& Media Studies, Gomal University, D. I. Khan, KP, Pakistan; ${ }^{5 *}$ Assistant Professor, Department of Sociology, Bacha Khan University Charsadda, Pakistan.

Email: ${ }^{1}$ raidafridiqau@gmail.com, ${ }^{2}$ drasifsalim@ bkuc.edu.pk, ${ }^{3}$ zarminafaiq@ gmail.com, ${ }^{4}$ komalmehreen21@gmail.com, ${ }^{5 *}$ kaleem@bkuc.edu.pk

Article History: Received on $10^{\text {th }}$ June 2021, Revised on $25^{\text {th }}$ June 2021, Published on $29^{\text {th }}$ June 2021

\begin{abstract}
Purpose: This paper intends to focus on elaborating on British colonialism and the types of indirect rule. The main purpose of the paper is to dig deep into the matter of how the British controlled the tribal societies and how far they were successful in controlling the tribal people. Indirect rule was designed to serve the interests of the British, whereas the tribes were left independent to deal with their internal affairs. It gives a detailed description of the British policy of controlling the tribes and answering the question of why the British opted for the indirect form of rule.
\end{abstract}

Method: The research work is qualitative and descriptive in which the already available information and facts about the contents are critically analyzed. Secondary sources such as books, research papers, journals, and online internet materials have been used to collect data related to this topic. The research work is analytical where qualitative techniques have been applied to investigate the major research question. The technique involves exploring different ideas and hypotheses related to ruling different colonies by the imperial administrators.

Main Findings: This study highlights that an indirect form of rule was the best strategy of the British colonial masters to control the unruly tribes. The hierarchical administrative structure which the British devised to control different areas of the world better served their interests where they rely on very few of their officers who controlled and administered the tribes. Another significant finding of the study is that the socio-political and economic underdevelopment in the postcolonial setup is because of the indirect form of rule which the British adopted during the colonization of the tribal regions.

Application of the Study: This study provides guidelines for further research to contemplate the links between indirect rule and the socio-political and economic underdevelopment in the post-colonial tribal areas of the world in general and in the erstwhile FATA (Federally Administered Tribal Areas) of Pakistan in particular.

The Originality of the Study: The study elaborates the concept of colonialism and the indirect rule of the British colonial masters and further explains how the British served their interests. It also linked the colonial legacies that continued in the tribal areas, which hampered their progress and development.

Keywords: Colonization, Indirect Rule, Tribe, Hierarchical Administration, Suzerain Rule, Hybrid Rule, De Jure Rule.

\section{INTRODUCTION}

During colonization, Great Britain encountered different tribal groups. It was an arduous task to control and rule over the tribal people. The tribal, for centuries, were living according to their traditions. The British administrators and anthropologists studied the tribal structure and proposed indirect rules to control these tribal societies. In studies of colonialism, indirect rule occupies a central place. Championed by Sir Frederick Lugard, indirect rule was shaped in such a hierarchical way were at the top, a British administrator ruled, and at the bottom level, the local chiefs were left independent to administer their day-to-day affairs. In this way, the local and, as well as the British administrators, worked together (Lugard, 1965; Gerring, Ziblatt, Gorp \& Arevalo, 2011).

In the studies of colonialism, indirect rule occupies a central place. Indirect control is categorized into a different form of governance like Suzerain, Hybrid, and De Jure, which are different from the direct control of Weberian Sovereignty (Gerth \& Mills, 1946). In Suzerain Rule, the colonized region exercises all power except its foreign policy, which is the domain of the colonizing power. The Hybrid form of rule is where the colonizer has their administrative set-up but where the local people are left independent in their sphere of life. The Government does interfere where and whenever the law and order situation deteriorates. In the De jure form of rule, the colonizers' control over the colonized state is nominal, the state is sovereign in the sense that it has its force and where usually the tax collection seldom pass to the high ups of the colonizing power. Different factors like strategic concern, revenue extraction, and social resistance resulted in the creation of these various forms of indirect rule during the colonial era. The decolonization after World War II led to the elimination of the Suzerain Rule, but Hybrid and De jure forms of indirect control remained in practice.

British rule in India and Africa provides a better case study for explaining the concepts of direct/indirect rule. Changes in the styles of rule were common. The direct type of rule resulted in establishing a single, uniform legal system, which was 
implemented in the colony. Whereas a dual system was in practice an indirect style of rule, which meant that both customary laws and the colonial system could run side by side.

\section{Theoretical Framework}

Tribal societies throughout the world have maintained their own identity. The tribal cultures inherently conservative resist normative changes imposed on them from outside, which may threaten their centuries-old traditions and cultures. The study has proceeded to keep in view the concept of 'Segmentary Societies' and the anthropological 'Glue Theory'. This helps us to understand the tribal structures and the whole political processes of colonialism and the post-colonial era. Segmentary societies are a decentralized and egalitarian social organization of groups having responsibility for security, defence, and welfare. They are descent groups having lineal descendants of a common ancestor. The concept of 'Segmentary Societies' better explains the structure of the tribal society and it also helps in comprehending the policy of indirect rule of the British for controlling the tribes. Whereas, 'Glue Theory' claims that it is difficult to create and accept changes in behavior in the presence of past norms. It provides an insight into the tribe's behavior of resisting change and their resistance to the colonial power. It is through the lens of these two concepts that give us a better understanding of ruling and controlling the tribes through indirect rule.

\section{Research Questions}

1. In what way(s) the British controlled tribal societies?

2. How far were they successful in controlling the tribal people?

\section{British Colonialism}

The eighteenth-century European states were struggling for supremacy in the international system. They believed in the extension of colonies as it gives prestige and status. The Europeans considered themselves superior and claimed that others were culturally inferior. The concept of White Man's Burden emerged where it was believed that it west's a responsibility to civilize the uncivilized part of the world (Khapoya, 2013). The major European powers like Great Britain, France, Belgium, and Italy colonized different world regions on various grounds. Different scholars pointed out varied reasons regarding colonization. Mazrui (1969) argued that it was the quest for knowledge that was to know the unknown, to spread the teachings of Christianity, and imperialist design to lay claims to other parts of the land. Other intellectuals like Klaus Knorr (1944) and John Hobson (1902) view seem much rational. According to them, reasons for colonization can be classified as political, cultural, and economic. Whereas economic factor on which most of the scholars agree is considered the actual reason that motivated the European powers to colonize other parts of the world. The greed for wealth, trade, resources, and cheap labour motivated European expansions into Africa and other parts of the third world countries.

The struggle for power among the European powers, technological and industrial superiority, and race for conquering and discovering other world regions were some of the causes of Imperialism. The nineteenth century saw the British Empire as the leading imperialist and colonial power. It was such a mighty Empire that had colonized and controlled most of the world, from the east to the west. The sun never sets on the British Empire was a famous slogan of that time. Their power depended on their trade and commerce. Means of communications and business at that time mainly were through oceans and seas. For that very reason, the United Kingdom focused on its naval power, thereby emerging as the most decisive maritime power on the world stage. Pursuing her power, political and economic interests, she had to secure the trading routes such as the Strait of Gibraltar, Strait of Malacca and Cape of Good Hope, etc. All this resulted in the rivalry between the British and other European powers. For commercial and mercantile benefits, the European powers were very much in the struggle for controlling and colonizing significant portions of the world (Bangash, 2016).

Europeans dominated most of the non-European people of the world in the last decades of the $19^{\text {th }}$ century. The rise and fall of empires have occurred in history, still, this modern form of imperialism created a unique situation in which European powers controlled far-flung noncontiguous regions of the world. This domination of different parts of the world occurred in various forms ranging from economic domination to occupation and annexation. None of the areas escaped intrusion from explorers, adventurers, traders, and missionaries (Abbattisto, 2011). Western Imperialism in the second half of the nineteenth century reached its pinnacle by colonizing much of Asia and Africa (Bangash, 2016).

Till the end of the nineteenth century, 90 percent of the continent of Africa, 57 percent of Asia and the whole of Australia, and almost 99 percent of the Pacific region were occupied and colonized by the European power. Colonialism was defended by the European forces on natural and political grounds. It was stated that the Christians would civilize the uncivilized world and that it is the responsibility of the civilized to govern the inferior races (Bangash, 2016). According to Robert Johnson (2003), British Empire in 1900 covered one-fifth of the globe and ruled around 400 million subjects of different ethnic groups and faiths. There were 60 dependencies were covering 3.2 million square miles, and British India consisted of a further 2 million square miles and 322 million subjects. Britain became the centre of the world, having such a vast territory and population, advanced trade system, communications, financial services, naval and military power. 
British Imperialism thus was considered a medium for enlightenment and civilization whose power was increased by colonizing territories through settlers or invaders. It was the political domination of people within a region. It included economic exploitation by utilizing their resources. The subjugated people were controlled militarily, and all the policies were made by the Imperial Power (Johnson, 2003). The course of British Imperialism used to vary according to the nature of the purpose and interest. British Empire took a long period to develop and expand where territorial acquisition occurred on very different grounds. During this expansion, strategically essential places such as Suez Canal, the scramble for Africa, and the North-West Frontier of India became the centres of diplomatic and military operations. The European powers started to rival Britain's strategically important possessions, which compelled the British to expand their influence into the interior of Africa and Asia (Johnson, 2003). When all these expansions were occurring during colonization, the British encounter with the tribes of Asia and Africa made them realize to devise a plan where the tribes could be controlled and where the interests of the colonizers could be attained. Indirect rule suited the tribal structure. Tribes were used as means of indirect rule. The British administrators used the term 'tribe' as it suits them. In the system of indirect control, the British colonial power used traditional rulers (chiefs) at the local level of government. They were empowered to maintain law and order and to impose the tax.

The British colonialists had successfully exploited the essence of tribalism in their colonized regions of the world. Colonization of different areas was later controlled through various methods where most of the areas were directly handled by the colonizers. However, those were other areas that were controlled indirectly. For centuries these tribal people were leading lives under their code of life. The British colonial masters did not interfere directly in the internal affairs of the tribesmen, and so adopted the policy of indirect rule.

\section{Defining Indirect Rule}

A form of political control of the areas where state authority cannot reach and where agents of the state delegate day-today governance to local power holders (Furnival, 2014). The local power holders hold traditional or customary authority who are the representatives of the ruler and enforce political leader on behalf of the rulers. In a direct form of rule, the area is controlled directly through bureaucrats where the state preserves the right to administer law and order without resorting to intermediaries. Another difference in the direct and indirect form of rule is the relationship of the colonial states with their individuals. Individuals under the direct law are related as citizens, whereas, in the indirect rule, they are subjects under power hierarchies (Mamdani, 1996). The studies of colonialism and post-colonial legacies have close relation with an indirect control. The colonial powers ruled the colonized territories in a distinctly different way. An Indirect form of law, characterized as a colonial form of governance, has not been discontinued or eliminated in many post-colonial nation-states. The day-to-day governance was delegated to the local traditional power holders while the rest was controlled by the colonial power. The areas which were located far-flung from the colonizers' location seemed difficult to be controlled through the direct form of government. The colonizing power exploited the intermediaries who were the traditional head of the tribes. Indirect rule from an institutional perspective can also be observed and understood by analyzing the weightage of authority given by the dominant unit to the subordinate units. It can be said that in a 'direct' style of rule, the power of making the decision is highly centralized, whereas, in an 'indirect' type of law, it is assigned to the lower section of society.

A question thus arises as to why certain colonies were ruled directly and others indirectly by the imperial administrators. Different hypotheses occur in this respect. The first one is the 'access hypothesis', which stated that state A's administration of rule over state B is dependent on the accessibility of state B to A. The greater the accessibility, the more will be the direct style of government, where accessibility means geographical contiguity, nearness or no transport barriers, etc. (Gerring, Ziblatt, Gorp \& Arevalo, 2011). The power hypothesis is that a state's capabilities like technological, military, bureaucratic, demographic, and economic define the style of rule over the subordinate units. The more state A is vital, the more it will exert direct control over B. There is another hypothesis, the revenue hypothesis, which stated that the style of the rule would be dependent upon the resources like tax revenue or access to the markets in the colonized unit or revenue from the natural resources. Thus the system of rule which will maximize revenue for unit A will be employed in unit B. Indirect forms of governance are therefore likely to be established where B enjoys a more state-like form of government (Gerring et al., 2011).

The theory of direct and indirect rule seems very much relevant to the type of imperial or colonial that existed between usually noncontiguous, asymmetric, and highly distinct units. The dominant unit ' $A$ ' in this relationship is referred to as the imperial power, colonial power, core or metropole, and the unit ' $\mathrm{B}$ ' which is the subordinate unit is referred to as a protectorate, dominion, colony, territory, trust, or client state. During colonization, it is evident that ' $A$ ' decides to create a new political authority that has the characteristics of an agent wherein authority has been bestowed on him by ' $A$ ' (Gerring et al., 2011). During the colonization of Africa and in the tribal region of India, the British administrators created chiefs who were bestowed upon with power by the British colonizer.

Frederick Lugard, a British colonial administrator, played a significant part in Britain's colonial history between 1888 and 1945, serving in East Africa, West Africa, and Hong Kong (Perham, 2016). He proposed a system of ruling through local leaders. This practice of ruling was there long before Lugard made it a doctrine for the British in Africa. During colonization in Africa, the British came to know that almost all the tribes have their chiefs who can serve the interests of the British in the frame of indirect rule, which was in practice in South Africa in the mid-19 $9^{\text {th }}$ century (Welsh, 1996). 
Lugard's vision of indirect rule can be traced back to Buganda (now Uganda), where the so-called Ganda Model played a prominent role in structuring the colonial administration. Buganda was divided into king-centred, hierarchical societies before colonialism. Europeans, on their arrival to Africa as colonizers, found the existing hierarchical structure beneficial for their ruling style. Thus the establishment of political systems in the form of districts was done based on presumed ethnic community inspired by the Ganda Model of Administration (Young, 1976). This idea of indirect rule, on the basis of the Bugandan Model, was formulated by Lugard and put into practice during his posting in Northern Nigeria (Maxon, 1994 \& Gartrell, 1983).

Lugard formulation of this plan got official recognition, and it was spread throughout the British colonial regime. Lugard's idea of indirect rule was to establish colonial administration in the far-flung areas, utilizing the local hierarchical structures of tribal societies. According to Evans Pritchard, tribal societies are organized based on the segmental lineage system. These groups usually lived outside state authority, have their territory, language, particular customs, and traditions. They have an organized mechanism for resolving conflicts and maintaining order where the role of the elder is prominent (Ahmad, 2013). His administration scheme was based on a system in which administration in the colony was to be in a clear descending order where British Governor was to be placed at the top. His vision of the settlement was that of a single unit in which the British administrators and the natives worked side by side (Lugard, 1965). The Indirect rule in the simplest form was a hierarchical pyramid in which the governor's position was on the top, and the other British officials and administrators worked below him. Territorial division of the colonies was furthered by making provinces that were sub-divided into divisions and districts. Province and district-level administrators oversaw the work of the local chiefs and village headmen. The administration, judicial and departmental branches were under the control of the governor and British officials. The local headmen or chiefs were supposed to be working under their traditions and statuses in their community. The local village headmen or tribal chiefs were in the lowest branch of the colonial hierarchy (Lugard, 1965). The local officers were thus played the role of mediators between the village headmen and the British high ups.

In the 1920s Africa, the British had many colonies like Nigeria, Gold Coast, Kenya, Sierra Leone, Gambia, Tanganyika, Uganda, Nyasaland, North and South Rhodesia, and South Africa. They were the separate units of the mother country. These colonial governments were almost independent in their decisions but with very little interference from the United Kingdom. Communication between them was in the shape of annual reports sent to the colonial office in London. Thus administration of the colonies was eventually led in very distinct ways (Berman, 1974). Lugard, for example, stated that in Kenya, the chiefs who were assigned administrative responsibility had the right to arrange armed groups to maintain their authority. In other colonies raising armed forces was forbidden for the native ruler (Lugard, 1965). The differences in the administration were because of the different geographical, political, and economic reasons. British administrators had diverse tasks to perform as that of administration, health, education, justice, and in some regions, the postal services depended on the geographical location of the colony. Lugard visualized the indirect rule to be moulded according to the different hierarchical structures. British officials with little knowledge and experience of administrators had to adapt Lugard's vision according to the surrounding realities. Before being appointed as an administrator of a specific district, the British officer was supposed to have some knowledge of the language and customs of that particular area.

The concept of indirect rule was very much suited to the British administrators as they instead, of detribalizing the people, supported their tribal ethnic groups. The hierarchical British administrative system was easy to transfer to the colonies where chiefs and sub-chiefs or village headmen became part of this system. The British also did not have sufficient resources to create new socio-economical and political institutions (Vail, 1989 \& Berman, 1974). Another reason for the feasibility of indirect rule was that it was much cheaper than direct rule. Hiring a massive number of British administrative staff was very costly, and there was also a scarcity of staff. Instead, the local chiefs were cheaper than the European administrators (Vail, 1989). Illife and Berman have pointed out that this structure of indirect rule gave the colonialists a moral right to rule. Because the colonialists were not interfering with the local practices of the people, they saw themselves as the saviours who would bring civilization to these savage people. The acquiescence of the local chiefs, headmen to these statements, gave acceptance to the justification of the British foreign rule (Illife, 1979 \& Berman, 1974).

\section{Types of Indirect Rule}

Indirect rule comprised of diverse forms of regulations promulgated in the various socio-political regions like that of tribal and day-to-day administration, political agencies, autonomous entities, and territories theoretically under direct administration but in reality dominated by the local tribesmen. To have a better understanding of the different forms of indirect rule, it is essential to identify various laws and to organize principles that the colonial powers constituted and promulgated for controlling other colonies and which the post-colonial states later on maintained, modified, or eliminated. These organizing principles or legal frameworks explain and identifies the colonizer's intentions of intervention and the status of its authority. The differences in these legal frameworks determine and clarify the different forms of governance. Based on the differences in legal frameworks, three distinct indirect forms of administration can be categorized as De jure, Suzerain, and Hybrid.

De Jure government means legal, legitimate, and so recognized by other states, wherein de facto, on the other hand, is the actual possession of power and authority. De jure government is a system of governance in which the state maintains 
direct rule over a territory, the real power of administration is held by the intermediate political elites. The legal framework is the same as Weberian Governance (the government claims the monopoly of the legitimate use of physical force within a given territory), still, its actual implementation does not resemble direct rule (Naseemullah \& Staniland, 2014). It is such a system of law where the local power holders, in reality, enforce the disciplinary norms and practices. An example of such a law can be quoted from India, where the states of Agra and Oudh (modern-day Uttar Pradesh or UP), was taken into control by the British from Mughal successor states after the 1857 rebellion. It was called the United Province, which was the most prominent British administrative province, theoretically was ruled under district magistrates, a Lieutenant Governor, and finally a Viceroy under the Indian Civil and Penal Codes. The hereditary feudal landowners in practice were the absolute rulers who collected taxes, seldom passing the revenue onward to the British Administration. They kept their forces for controlling their territories (Robinson, 1974).

In Suzerain rule, the dominant state controls the foreign relations of a vassal state but allowing its sovereign authority in its internal affairs (Naseemullah \& Staniland, 2014). The princely states or tribal groups are independent in name only and constitutionally free to order and maintain their internal affairs, still, they have obedience and devotion to the widespread extensive imperial power. Individuals under the Suzerain rule are subject to either the explicit laws or the customary norms of the subject state or social group, as well as the government or other political organization upholding them, without any recourse to the laws of the colonizing state (Naseemullah \& Staniland, 2014).

During colonization, certain territories were strategically important for the imperial powers, but they were not able to fully occupy and control those regions. In such areas where a monopoly of force could not be established, the colonizing power established a Hybrid form of governance structure. In such a type of governance structure, the state shares authority with social actors. The Hybrid rule is differentiated from the Suzerain rule because of the two features. First, the colonizing power's intervention is legally codified in legal frameworks which differ from both the laws and customary practices of the princely states. Second, the instruments of coercive force are kept by the state in the form of special levies, militia, and constabularies along with those supported or controlled by the traditional elites (Naseemullah \& Staniland, 2014). Hybrid thus presents a unique case of governance structure. An example of such governance can be quoted from the North-West Frontier's tribal agencies, where tribal levies later on Frontier Corps were deployed and until 1947, where permanent military encampments were there for supporting the dual authority of the Political Agent and the tribal Malik or Chief (Naseemullah, 2014). This Hybrid form of governance was structured in the legal framework of Frontier Crimes Regulation (FCR) in 1901, wherein the collective responsibility clause was there to control the tribes from crimes and offences against the state.

\section{The Problem of Political Control}

With colonization, the colonizers faced the problem of political control. To extract resources from any colonized area, or to claim sovereignty over that area the colonizers' primary concern was that of the political order. To achieve their objectives from the occupied territory, the colonizers have to deter the potential rebellion to earn a certain degree of peace and tranquillity. Therefore it not only depends on the use of force but also on legitimacy where the passion and control over the region be considered legitimate (Gerring et al., 2011). Power alone cannot serve the purpose in this case. Soldiers and bureaucrats can immediately be moved to the colonized region, until and unless local support and consent are not provided, the interests of the colonizer cannot be attained. It is therefore evident that the preexisting political institutions can be of very much help. Thus indirect rule serves best the interests of the colonizers.

By not disturbing the existing structure that is political/social structures at the state level or a specific tribal, regional level, several immediate benefits can be gained. By studying and observing different tribal structures, the British colonizers felt that it would be beneficial to rule these areas indirectly. Because they would be able to maintain political order at a meagre cost, with little or no deployment of personnel and material. Where indirect rule serves better, the direct style of law creates problems, requires the destruction of already existing political order, where it becomes difficult for the colonizers to control the colonized region. It is not a matter of politics alone, for politics is interconnected with the issues of culture, identity, ideology, and dignity. The direct rule often led to more significant opposition, revolts, and unrest as compared to indirect control. In the pretext of this discussion, it can be said that indirect control may be conceptualized as a species of "soft power" (ye, 2004).

The benefits of the indirect rule are thus much higher as compared to the direct form of governance. The preexisting prevailing system is usually more accessible, for the colonizer to utilize. Preservation of the existing political structure, as compared with recreation (which would be the case indirect style of rule), is less expensive, more predictable, and less filled with complications.

\section{Leadership Role in Indirect Rule}

In an indirect form of rule, the role of leadership cannot be ignored. It is the style of the rule, which can be termed as a negotiated settlement. An indirect form of rule without the active participation of the leaders from both units A and B cannot be materialized. Where direct rule rests on coercion, the indirect law requires bargaining and negotiations. In the indirect rule, the dominant power holds most of the cards wherein the leaders of the colonized unit have the option of refusing to sign agreements. They may resort to violence, but it may be displeasure to A. It can be noted here that where it is stateless (the capacity of the state to exercise its fundamental functions) and political order in the colonizing unit, the 
leaders in that situation are usually wealthy, esteemed personalities. Thus in the case of confrontation, they are in the most vulnerable position. Their privileges, status, wealth are an easy target via military attack, economic boycott, etc. by the colonizing power. Thus in such a case, the political institution is much more vulnerable that can easily be attacked and destroyed. In such cases, agreements do occur successfully.

In the less politically institutionalized society where there is less political order having local tribal chief as their leader or acephalous society where there are multiple leaders at the lower level with limited authority over small areas, the leadership vulnerability is less to threats from the strong outside power. Leaders at this level in such societies are difficult to be identified, capture, and punished. They have nothing to lose; thus usually challenging to be tamed. They are not quickly washed out by military incursion because the political power in such societies can easily regenerate. Leadership in such a structure does not depend upon formal organizational structures, central administrative offices, and advanced logistics. Leaders in a developed polity will likely cooperate with the superior power. Cooperation thus is a necessary element and condition for indirect control (Gerring et al., 2011). Indirect rule served the interests of the British very well. The system was such that the administrative task was divided among the locals that hampered political consciousness among the people (Vail, 1989). The divide and rule concept became visible in which the British kept the local groups separated from each other so that they could easily be controlled more systematically. The locals were kept far from uniting, which provided the colonizers more space and time to organize the administration of the local people.

For controlling tribes, the British, by adopting the indirect form of rule during colonization, started drawing maps of the tribal areas on tribal lines. The tribal units thus formed acted as the administrative units. The British colonial administration was built up around the idea of these tribes. Attaching territory with ethnicity was the primary measure adopted by colonialists to control the native people. Tribes were the basic units in the hierarchy of indirect rule led by their chiefs. Through the tribal chiefs, the British colonial administrators controlled the native tribesmen. In this way, the whole system of indirect administration worked.

\section{CONCLUSION}

The pretext of colonization given by the colonial powers was to know the unknown and to civilize the uncivilized world. British Empire in the $19^{\text {th }}$ century emerged as a leading imperialist and colonial domination. Of all the factors that were political, cultural, and economic, the greed for wealth, trade, resources, and cheap labour was the primary factor for colonization. It was all based on the struggle for power and domination of the world.

The indirect rule though better served the interests of the British colonial power without utilizing much of their resources and avoided unnecessary confrontation with the tribes for controlling them but the continued colonial legacies especially in the tribal areas greatly hampered their socio-political and economic developments. Direct and indirect colonialism have a long-lasting impact in shaping the political phenomenon in the post-colonial structure. The directly ruled areas or settler-colonial countries became much more democratic and tends to have a higher contemporary level of education and income. In the case of indirect rule, the mechanism of administration was to work with traditional authorities which emerged as a parallel despotic governance structure. These traditional authorities than in the post-colonial political structures undermine individual support for democracy and the rule of law. In the direct rule, the colonial power established centralized, territory-wide, bureaucratic legal administrative institutions which were controlled by the colonial officials. Examples of directly ruled British colonies were Sri Lanka, Barbados, Australia, etc. In the case of indirect rule, the colonial domination of the areas was through collaboration with the local intermediaries. The local chiefs, princes, and leaders of the tribe controlled customary legal administrative institutions where they worked in collaboration with the colonial officials. Most of the areas of British Africa and British India experienced this type of governance. The princely states in British India and the tribes of the North-West Frontier is a good example of indirect colonial rule. These areas after independence had limited legal administrative capacities and thus failed to develop exponentially.

British during colonization encountered different tribes. To better serve their interests in the tribal areas, they came up with the idea of indirect rule wherein the tribal chief or elder was to control his tribe on the condition of some economic benefits provided to him by the colonial authority. This system of administration was much cheaper as the British only had to appoint a colonial administrator at the top who only had to deal with the tribal chief. People were divided into clear units based on tribalism which made it easier for the colonial British to control them. Everyone belonged to a certain tribe. It was the best idea of keeping order and controlling the tribesmen. Every single native was under one chief and lived in some specified area. In the indirect rule tribe as a term was the identification of tribesmen, which was used to specify the subordinate masses to the British administrators. Actions thus taken against a tribal man were directed towards specific tribes. Penalties if inflicted on an individual were to be directed towards specified units. The tribes for example were given collective punishment for offences like stealing stocks or conducting raids on British convoys. This act of collective punishment indicated that the natives lived in tribal groups and because of close affinity with each other the whole tribe or community was to be responsible for the actions of its members.

British colonialists being sociologists and anthropologists better understood the tribal societies and thus devised an indirect form of rule to administer these tribal groups. Tribal societies having segmentary lineage structures fit well in 
the British hierarchical administrative system. Avoiding confrontations with the tribes the British through the indirect form of rule better served their colonial objectives.

\section{AUTHORS CONTRIBUTION}

Raid Khan has devised the main idea and wrote the research paper. Asif Salim has developed the research design and analysed the data. Zarmina Baluch has polished the main findings thoroughly. Komal Mehreen\& Muhammad Kaleem revised the article and finalized it.

\section{REFERENCES}

1. Ahmad, S. A. (2013). The thistle and the drone. India: Harper Collins.

2. Bangash, S. (2016). The Frontier tribal belt: Genesis and purpose under the Raj. Pakistan: Oxford University Press, p.23.

3. Berman, B. J. (1974). Administration and politics in colonial Kenya. Michigan: Ann Arbon.

4. Furnival, J. S. (2014). Colonial policy and practice. Cambridge, UK: Cambridge University Press. https://doi.or g/10.1017/CBO9781107051140

5. Gartrell, B. (1983). British administrators, colonial chiefs, and the comfort of tradition: An example from Uganda. African Studies Review, 26(1), 1-24. https://doi.org/10.2307/524608

6. Gerth, H. H. \& Mills, C. Wright. (1946). Translated and edited. From Max Weber: Essays in Sociology. New York: Oxford University Press, pp., 77-128.

7. Gerring, J., Ziblatt, D., Gorp, J. V. \& Arevalo, J. (2011). An institutional theory of direct and indirect rule. World Politics, 63(03), 377-433. https://doi.org/10.1017/S0043887111000104

8. Hobson, J. A. (1902). Imperialism: A Study. New York: James Pott \& Co. Retrieved from https://oll.liberty fund. org/titl es/hobson-mperialism-a-study

9. Illife, J. (1979). A modern history of Tanganyika. Cambridge: Cambridge University Press. https://doi.org/10.10 17/CBO9780511584114

10. Johnson, R. (2003). British Imperialism. New York: Palgrave Macmillan. https://doi.org/10.1007/978-1-40394031-5

11. Khapoya, V. B. (2013). The African experience: An introduction. New York: Routledge.

12. Knorr, K. E. (1944). British colonial theories, 1570-1850. Toronto: University of Toronto Press. https://doi.org/10.3138/9781487589394

13. Lugard, F. D. (1965). The Dual Mandate in British Tropical Africa (5 ${ }^{\text {th }}$ Ed.). London: Frank Cass \& Co. Ltd.

14. Mamdani, M. (1996). Citizen and subject. Princeton, NJ: Princeton University Press.

15. Maxon, R. M. (1994).East Africa: An introductory history( $2^{\text {nd }}$ Ed). Nairobi: East African Educational Publishers

16. Mazrui, A. A. (1969). European Exploration and Africa's self-discovery. The Journal of Modern African Studies, 7 (4). 661-676. https://doi.org/10.1017/S0022278X00018887

17. Naseemullah, A. (2014). Shades of sovereignty: Explaining political order and disorder in Pakistan's North West. Studies in Comparative International Development, 49(4), 501-522. https://doi.org/10.1007/s12116-0149157-z

18. Naseemullah, A. \& Staniland, P. (2014). Indirect rule and varieties of governance. Governance: An International Journal of Policy, Administration and Institutions, 29(1), 13-30. https://doi.org/10.1111/go ve. 12129

19. Nye, J, S., Jr. (2004). Soft power: The means to success in world politics. New York: Public Affairs.

20. Perham, M. (2016). Frederick Lugard: British colonial administrator. In Encyclopedia Britannica. Retrieved from https://www.britannica.com/biography/Frederick-Lugard.

21. Robinson, F. (1974). Separatism among Indian Muslims: The politics of the United Provinces' Muslims, 18601923. New York: Cambridge University Press.

22. Vail, L. (1989). The creation of tribalism in southern Africa. London Berkeley: Currey University of California Press. http://ark.cdlib.org/ark:/13030/ft158004rs/

23. Welsh, D. (1996). Ethnicity in Sub-Saharan Africa. Royal Institute of International Affairs 1944, 72(3), 477491. https://doi.org/10.2307/2625552

24. Young, C. (1976). The politics of cultural pluralism. USA: University of Wisconsin Press. 